\title{
CORONAVIRUS, LOCKDOWN, AND ECONOMY
}

\author{
Helmuth Yesid Arias Gomez \\ The University College of Business in Prague, Czech Republic
}

\section{Gabriela Antosova}

The University College of Business in Prague, Czech Republic

\section{CMESTE}

JEL Category: I15, H51, H63

\begin{abstract}
Humanity has faced an unprecedented biological threat that collapsed the global economy and engulfed the animal spirits in a severe wave of pessimism and fear. The measures of policy have combined an expansive monetary policy and an extra fiscal expenditure that was not contemplated in the budgetary planning exercise. The recuperation stage is strongly challenging and requires all efforts of economic policy. The future global economic performance relies on the breaking policy postures that can succeed in realigning the path of growth in the long run. In any case, the destruction in the economic network and employment is so hard to restore that we must avoid the risk is to align the economy in a more stagnant path of growth for the future. The concluding part of the paper states that during the pandemic we saw that the way ahead should not be headed by the market mechanism but instead by an openly interventionist economic policy. In this blatantly ominous stage of the economy, serious doubts emerged about the ability of spontaneous supply and demand forces to recover the economic structure left in shambles by this disruptive shock.
\end{abstract}

Keywords: Economic Growth, Healthcare, Economics, Epidemiology.

\section{INTRODUCTION}

The lethal irruption of Coronavirus in the world agenda surprised governments all around the world and put under pressure the most complete health system. The vertiginous pace of contagion was only stopped with a general rigorous lockdown, but the bound economic consequences and the destruction of thousands of labor posts came along simultaneously. This extreme measure gave a blow to sectors operating on the

Address of the corresponding author: Goméz Helmuth Yesid Arias

䒠=gomez@vso-praha.eu knife-edge as airlines and weakened all tourism services and manufacturing sectors.

Facing such a landscape, the entire economic system must resort to outright Keynesian recipes to lift the economy. Everywhere, the collapse of the private economy has required the intervention of governments extending loans, or through outright purchasing of enterprises. It's clear that the entire origin of the crisis comes from a health problem, so no market mechanism will take the initiative for solving it, and a large scale and coordinated action must be tackled by a blatantly activist economic policy (Lustig \& Mariscal, 2020). 
Gazing such a situation, the upshot is that a long process of locking down can lead the economy into an unforeseen depression. So, such a tradeoff between the economy and public health will be

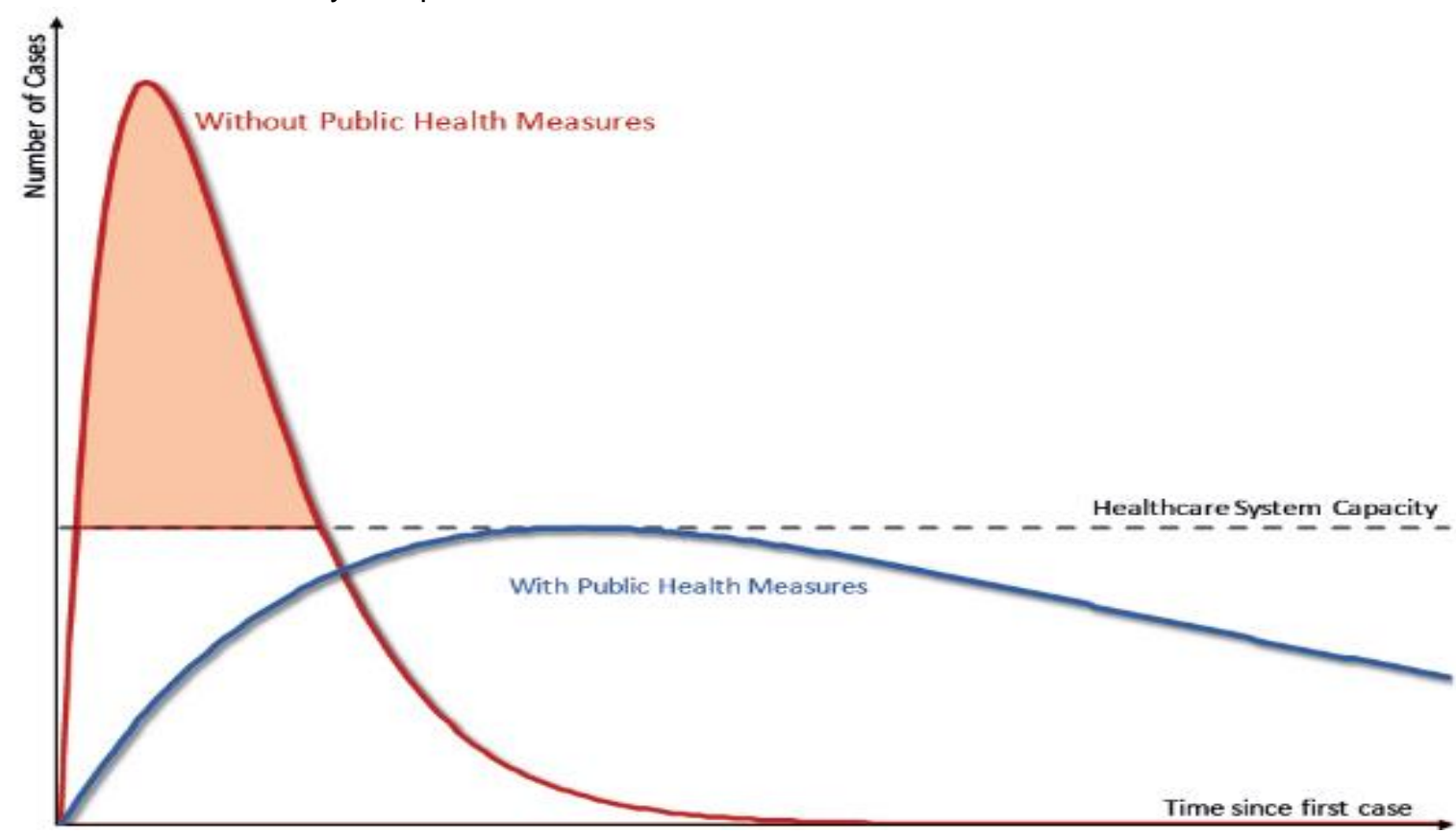

a strong headache for all governments and becomes a dilemma for the public and workers of affected countries.

Fig. 1 Scenarios for coping with the pandemic.

Source: (Gourinchas, 2020)

In a very recent document, Gourinchas (2020) proposed the illustration that appears in figure 1.

In the first moment, the outbreak of pandemic put pressure on the health systems and the saturation of sanitary infrastructures is an indicator that the incipient stages of the disease are developing. After this, the system realizes that there is a constraint that allows the provision of health services using the available stock of equipment and premises (the flat line depicted after a while).

So far, consulting diverse documents and sources, the more effective strategy for containing the spread of disease is the general locking down, with exclusive permission for essential jobs and sectors.

The general indicator for recognizing the state of the disease is the called reproduction number $(R)$ that represents the number of people infected because of only one individual. In Arroyo Marioli, Bullano, Kucinskas, \& Rondon-Moreno (2020) appears one method for estimating econometrically the number $\mathrm{R}$, applying the Kalman Filter. For the estimation, the necessary data are the infected, the susceptible people, and the recovered.
The ratio of infection $\mathrm{R}$ must be slowed either by restricting stringently the interpersonal contact through teleworking, the closure of schools and non-essential business activities, and the prohibition to traveling or through the isolation in the quarantine of the infected people.

In figure 2 appears the path of the estimation of $R$ for the world.

During January 2020, the Chinese cases increased but, in the end, the decline in the number of infected marked a reduction, interrupted at the beginning of February. On February 19th, the disease for the world exploded again including the extension of pandemic around Europe and the USA. The generalized declaration of locking down in Europe during the middle of March contributed to sharply reduce the effective contagion. However, the slope in the curve was more flattened embodying the European behavior of pandemic, than the Chinese incidences when the rate of reduction was faster. A recent second wave was demonstrated to be even more disruptive. 


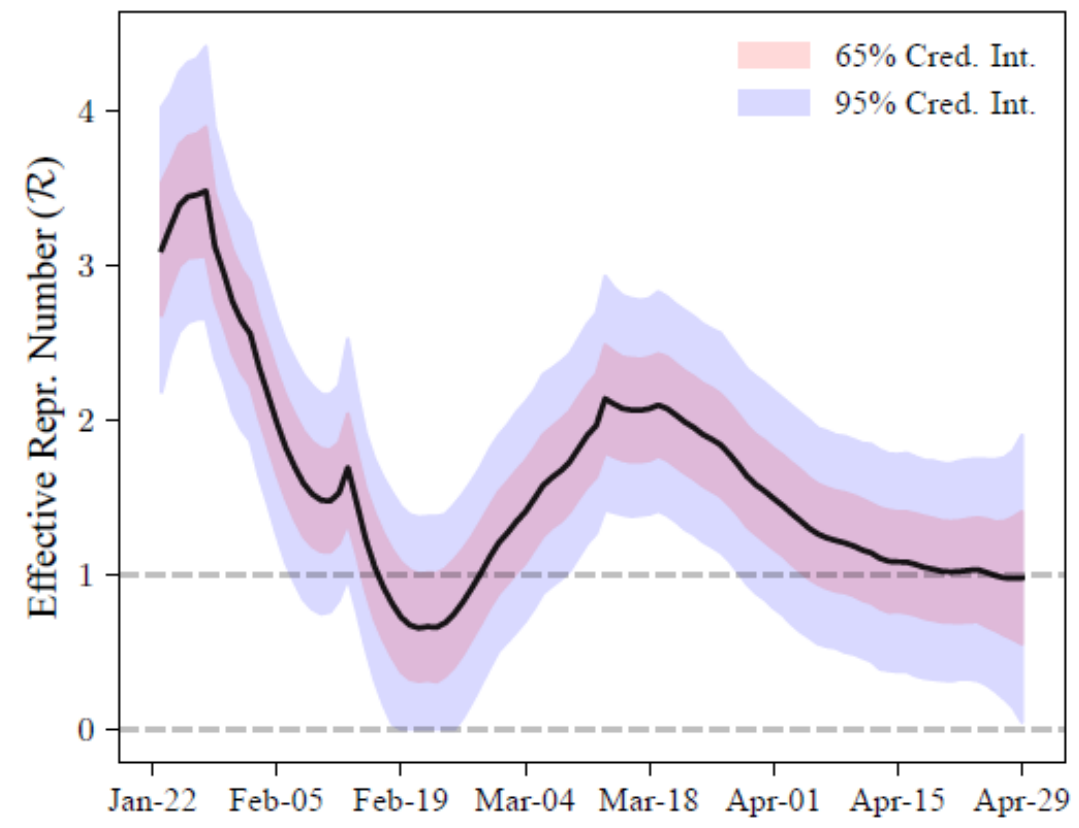

Figure. 2 Estimates for the world.

Source: Arroyo Marioli, Bullano, Kucinskas, \& Rondon-Moreno (2020)

\section{CORONAVIRUS IN VISEGRAD GROUP}

The devastating initial effects of COVID-19, affecting in the first stage China, Korea, Iran, and Italy, became the pandemic in a more predictable social problem. The pandemic in four countries V4 had more moderate development due to the early measures of locking down. The Italian and Spanish striking increasing curve of cases, the fast pace of contagions, and the huge impact on the local health system was a shake for all neighboring European countries and precipitated the early issuance of strict measures of social distancing. The locking down was the final extreme measure after the staggering of previous preventive decisions: the closure of schools, the banning of public events, and the social distancing.

The blatant outbreak of COVID-19 shocked the markets primarily through a generalized drop in the production, hitting the supply side but, afterward, the banning of personal contact and locking down knocked down the employments of millions of people around the world, converting the global downturn into a demand shortfall as well. The general expectation weakened also as a reaction to the deterioration of financial values and the downfall in stock markets, precipitating a badly connected chain of recessive tensions (Lane,
2020). The demand contraction comes from the tough measures of social distancing as the single effective measure for containing the spread of the pandemic, and in consequence, the collapse in demand has driven by the deep retrenchment of consumers' demand (Lustig \& Mariscal, 2020).

In the Czech Republic, confinement began on the $16^{\text {th }}$ of March and was eased on the $11^{\text {th }}$ of May, after a reduction in the incidence of disease, and similar measures were undertaken in other partners of V4. It's observed that locking down has an important effect to stop the infectious process.

In Poland, the first isolation measure was taken on the $13^{\text {th }}$ of March closing the borders, and on the $24^{\text {th }}$ of March started the locking down, except for essential activities. The Polish government plans to ease the confinement on 19 of May 2020.

In Serbia, in early March were reported the first confirmed cases of the virus, a situation that drove the government to close the borders and to impose closure in schools and educational institutions.

In Slovakia, during the first half of March were closed all schools and all public events were banned, while people arriving from abroad had to be submitted to quarantine. And on the $22^{\text {nd }}$ of April, the restrictions gradually started to ease. 
Hungary adopted a stringent strategy of control since the first cases reported at the end of February. On the $11^{\text {th }}$ of March were disposed the closure of in-person classes only at Universities, a restriction that was extended to other educational levels afterward. Regarding the access from abroad, on the $16^{\text {th }}$ of March was forcefully banned the entry to any non-resident person, after that the prohibition was imposed in a selective way to visitors coming from specific affected countries.

The recent outbreak of cases during the second wave, obligate to resume the most restrictive measures everywhere

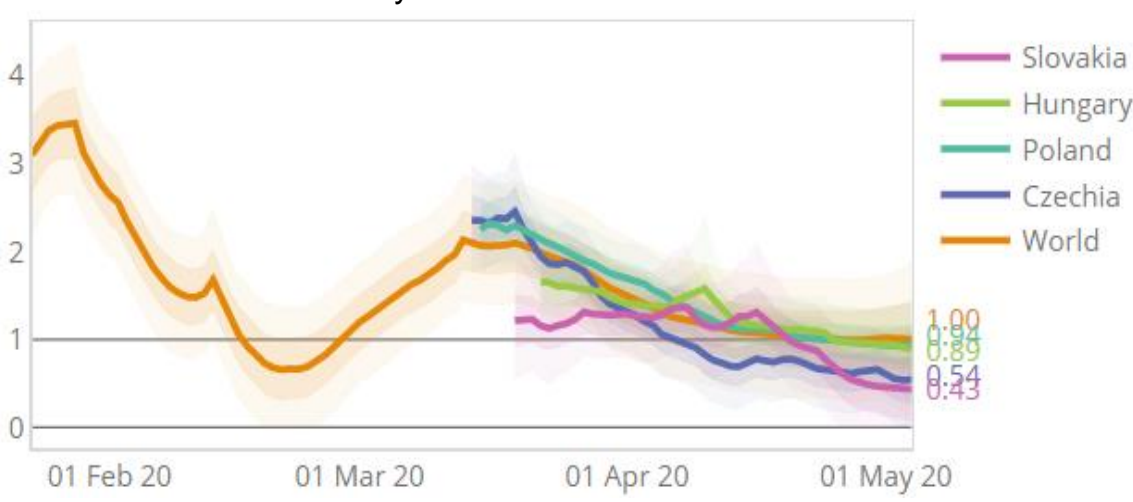

Figure 3 Effective reproduction number in V-4.

Source: Adopted by Source Rondn-Moreno \& Marioli, Bullano (2020)

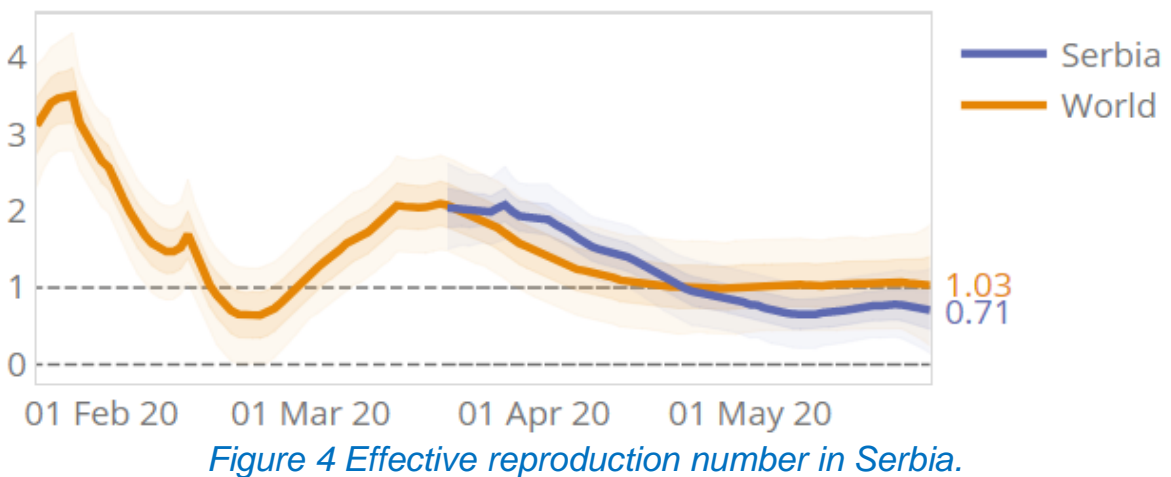

Source: Adopted by Rondon-Moreno \& Marioli, Bullano (2020)

\section{PERSPECTIVE FOR THE WORLD ECONOMY}

The global effects of locking down around the world have been devastating for the global economy in terms of economic growth, employment, and the rise of poverty. In the developing world, provided the preexistent poverty and economic informality dropped into starvation a large portion of the population and in the developed world, the requirement for social subsidies has risen sharply. In Spain, previously families living a normal life and recurrent incomes, are now obligated to stand in the ques asking for food.
Table 1. Forecasted Economic Growth 2020.

\begin{tabular}{|l|c|}
\hline & $\begin{array}{c}\text { GDP Growth } \\
2020\end{array}$ \\
\hline Austria & -5.5 \\
\hline Belgium & -7.2 \\
\hline Estonia & -6.9 \\
\hline Finland & -6.3 \\
\hline France & -8.2 \\
\hline Germany & -6.5 \\
\hline Greece & -9.7 \\
\hline Italy & -9.5 \\
\hline
\end{tabular}

\begin{tabular}{|l|c|}
\hline & $\begin{array}{c}\text { GDP Growth } \\
2020\end{array}$ \\
\hline Latvia & -7.0 \\
\hline Lithuania & -7.9 \\
\hline Luxembourg & -5.4 \\
\hline Malta & -5.8 \\
\hline Netherlands & -6.8 \\
\hline Portugal & -6.8 \\
\hline Slovakia & -6.7 \\
\hline Slovenia & -7.0 \\
\hline
\end{tabular}

\begin{tabular}{|l|c|}
\hline & $\begin{array}{c}\text { GDP Growth } \\
2020\end{array}$ \\
\hline Spain & -9.4 \\
\hline Cyprus & -7.4 \\
\hline E. U. & -7.4 \\
\hline Euro Zone & -7.7 \\
\hline Ireland & -7.9 \\
\hline U. K. & -8.3 \\
\hline
\end{tabular}

Source: European Commission 
From economic science, a lot of scholars have issued recommendations and suggestions under severe concerns about the devastating effects of the pandemic itself and the lockdown measures. Paul Romer (2020) compared the huge cost of close mostly the economy and the inconvenience derived of enforce a massive COVID-19 test effort, aiming to isolate the infected population, but permitting the remainders to work normally. Acemoglu (2020) hinted that all social media data can be useful for tracking the routines of the population to avoid the propagation from the infected individuals, as an invasive strategy against the privacy of people, with the caveat of recovering the privacy in the post-pandemic stage.

The hard dilemma between recession and health is deployed by Baldwin and Weder di Mauro (2020) as shown in figure 5 .

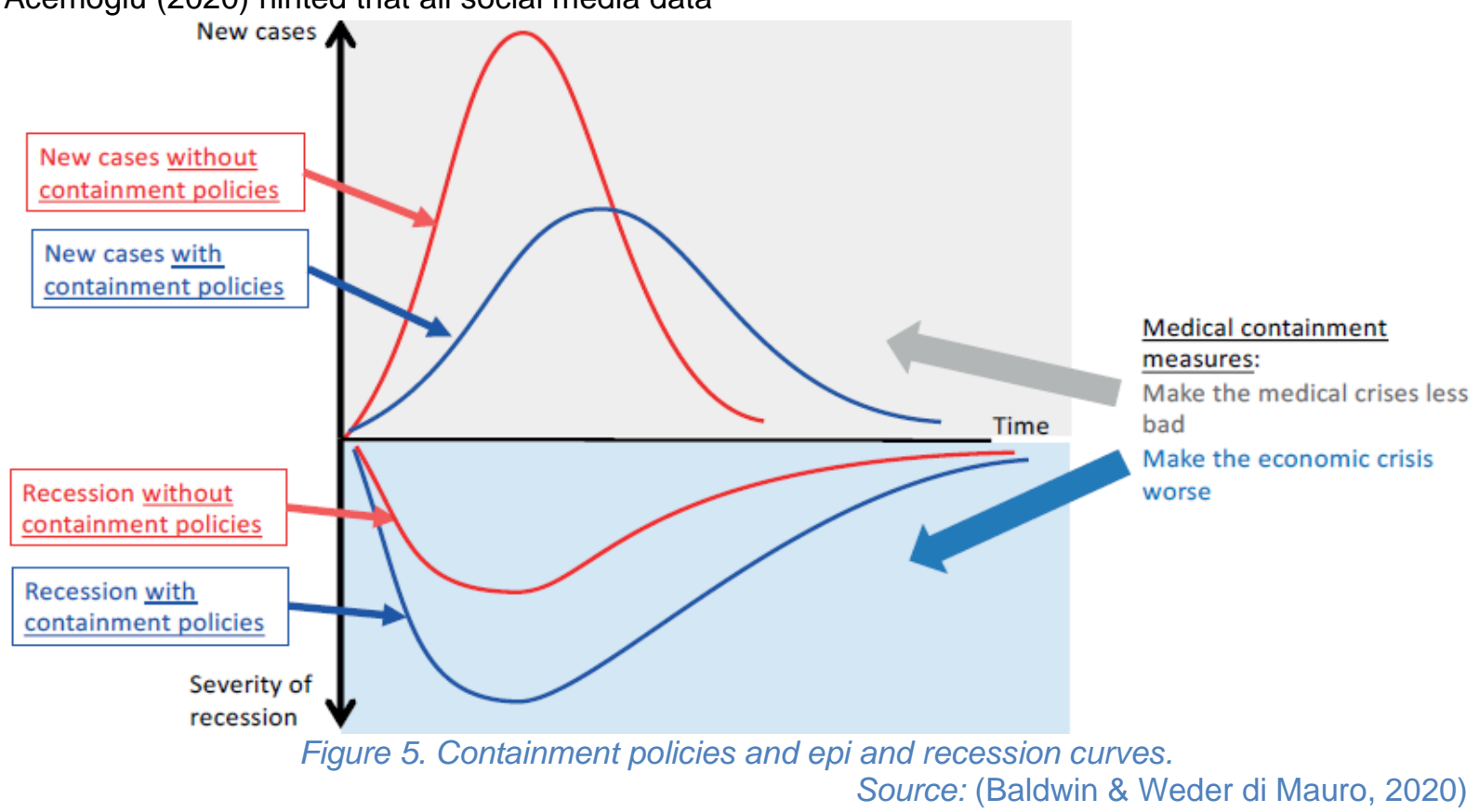

The arguments of Romer (2020) can be understood considering other scientific opinions who consider that once the data have been collected, the statistics about the effects of the pandemic are less dramatic. The massive application of tests indicated that infected people were more manifold, and the rate of mortality is

Table 2. Forecasted fiscal stance in 2020.

\begin{tabular}{|l|c|c|}
\hline & $\begin{array}{l}\mid \text { Fiscal balance } \\
2020\end{array}$ & $\begin{array}{l}\text { Debt-GDP ratio } \\
\text { of 2020 }\end{array}$ \\
\hline Austria & -6.1 & 78.8 \\
\hline Belgium & -8.9 & 113.8 \\
\hline Estonia & -8.3 & 20.7 \\
\hline Finland & -7.4 & 69.4 \\
\hline France & -9.9 & 116.5 \\
\hline Germany & -7.0 & 75.6 \\
\hline Greece & -6.4 & 196.4 \\
\hline Italy & -11.1 & 158.9 \\
\hline Latvia & -7.3 & 43.1 \\
\hline Lithuania & -6.9 & 48.5 \\
\hline Luxembourg & -4.8 & 46.4 \\
\hline
\end{tabular}

now more reduced. And to the extent that the symptoms hound more outrightly the elderly and people with preexistent diseases. At this point, the real risk of COVID-19 is the fatal contagiousness of the virus and the prompt expansion amid the population.

Source: Adopted by the European Commission.

\begin{tabular}{|l|c|r|}
\hline & $\begin{array}{r}\text { Fiscal } \\
\text { balance } \\
2020\end{array}$ & $\begin{array}{r}\text { Debt-GDP } \\
\text { ratio of } \\
2020\end{array}$ \\
\hline Malta & -6.7 & 50.7 \\
\hline Netherlands & -6.3 & 62.1 \\
\hline Portugal & -6.5 & 131.6 \\
\hline Slovakia & -8.5 & 59.5 \\
\hline Slovenia & -7.2 & 83.7 \\
\hline Spain & -10.9 & 115.6 \\
\hline Cyprus & -7.0 & 115.7 \\
\hline E. U. & -8.3 & 95.1 \\
\hline Euro Zone & -8.5 & 102.7 \\
\hline Ireland & -5.6 & 66.4 \\
\hline U. K. & -10.5 & 102.1 \\
\hline
\end{tabular}


The economic policy runs amid two circumstances: a generalized reduction in the interest rate and an explosive expansion of public debt. The irrigation of cheap loans can contribute to staying afloat the firms that previously to crises, performed adequately.

European emergency funds are expected to relaunch the more depressed economies across the continent, particularly Italy and Spain.

The management of fiscal policy is strongly more challenging provided the acute impairment in the tax collection, the explosion of public expenditure, and the escalation of public debt. This fiscal landscape has an aggravating circumstance if highly indebted countries as Spain and Italy were hit by the pandemic head-on.

This unexpected nosedive in economic activity and employment was provoked by a sudden shock with straightforward recessive consequences, but a more disruptive concern is the risk to become this downturn in a permanent weak path of growth that in the long run can reduce the economy's potential of growth (Lane, 2020). A blatantly lasting reduction in the growth of the economy can be a latent risk to the extent that large portions of business net disappear promptly, and the reincorporation of the labor laid out by pandemic will be a hard task.

\section{CONCLUSIONS}

The lethal track of coronavirus in V4 countries was initially more moderated regarding other European partners (Italy, Spain, Germany, and France), due to the fast application of isolation measures, the lockdown, and the erection of border controls. The social discipline observing the restriction bolstered the general strategy of contention.

On the other hand, the rigorous measures of locking down and the social distance struck a hard blow to the general economy and employment. The enlargement of confinement and social restrictions will deepen the economic crisis experienced by airlines, hotels, businesses, transports, and several services.

The reviving of the Keynesianism more interventionist see Keynesianism as the single feasible measure to lift the economy after the pernicious prostration left by the striking irruption of COVID-19.

On the monetary front, all the load of measures is required for avoiding a general collapse in the economy and a weakening of the banking system.

Considering the precarious equilibrium posed for businesses and enterprises in the post-pandemic, the recoupment of the fiscal revenue must come from spurring the economic growth but not from the increase in taxes.

This pandemic opened our eyes to some risk ahead, that can come from climate change or biological factors.

During the pandemic, we were convinced that the way ahead should not be headed by the market mechanism but instead by an openly interventionist economic policy. In this blatantly ominous stage of the economy, serious doubts emerged about the ability of spontaneous supply and demand forces for recovering an economic structure left in shambles by such disruptive shock.

After the initial outbreak and the second wave of the pandemic, perhaps the most promising solution is the widespread implementation of the vaccine. Mass application of it could contribute to resume normality and to recoup the huge economic losses in terms of employment and output across the world.

\section{WORKS CITED}

Acemoglu, D. (2020, Apr 20). La sociedad debe permanecer vigilante ante el avance del Estado. (L. Torras, Interviewer) Retrieved from https://www.elmundo.es/economia/actualidadeconomica/2020/04/20/5e99c241fdddff964d8b4581.html

Arroyo Marioli, F., Bullano, F., Kucinskas, S., \& Rondón-Moreno, C. (2020, May 10). Tracking $R$ of COVID-19: A New Real-Time Estimation Using the Kalman Filter. doi:10.2139/ssrn.3581633

Baldwin, R., \& Weder di Mauro, B. (Eds.). (2020). Mitigating the COVID Economic Crisis: Act Fast and Do Whatever It Takes. London: CEPR Press. 
Gourinchas, P.-O. (2020, June 03). Flattening the pandemic and recession curves. Retrieved from VOX: https://voxeu.org/article/flattening-pandemic-and-recession-curves

Lane, P. R. (2020, Mar 13). The monetary policy package: An analytical framework. Retrieved from European Central

Bank: https://www.ecb.europa.eu/press/blog/date/2020/html/ecb.blog200313 9e783ea567.en.html

Lustig, N., \& Mariscal, J. (2020, Mar 18). How COVID-19 Could Be Like the Global Financial Crisis (Or Worse). Retrieved from Center for Global Development: https://www.cgdev.org/blog/how-covid19-could-be-global-financial-crisis-or-worse

Romer, P. (2020, May 1). \$11 billion for Testing by States Could Run Out in 8 Days. Retrieved from paulromer.net: https://paulromer.net/uses_for_tests/

Rondon-Moreno, C. \& Marioli, F. \& Bullano, F. (2020). Dynamics of Transmission and Control of COVID19: A Real-time Estimation Using the Kalman Filter. 10.1101/2020.04.19.20071886.

Received for publication: $\quad 06.09 .2020$

Revision received: $\quad 28.11 .2020$

Accepted for publication: $\quad 30.12 .2020$

\section{How to cite this article?}

Style - APA Sixth Edition:

Gomez, H. Y., \& Antosova, G. (2021, January 15). Coronavirus, lockdown, and economy. (Z. Cekerevac, Ed.) MEST Journal, 9(1), 8-14. doi:10.12709/mest.09.09.01.02

Style - Chicago Sixteenth Edition:

Gomez, Helmuth Yesid Arias, and Gabriela Antosova. 2021. "Coronavirus, lockdown, and economy." Edited by Zoran Cekerevac. MEST Journal (MESTE) 9 (1): 8-14. doi:10.12709/mest.09.09.01.02.

Style - GOST Name Sort:

Gomez Helmuth Yesid Arias and Antosova Gabriela Coronavirus, lockdown, and economy [Journal] // MEST Journal / ed. Cekerevac Zoran. - Belgrade - Toronto : MESTE, January 15, 2021. 1 : Vol. 9. - pp. 8-14.

Style - Harvard Anglia:

Gomez, H. Y. A. \& Antosova, G., 2021. Coronavirus, lockdown, and economy. MEST Journal, 15 January, 9(1), pp. 8-14.

Style - ISO 690 Numerical Reference:

Coronavirus, lockdown, and economy. Gomez, Helmuth Yesid Arias and Antosova, Gabriela. [ed.] Zoran Cekerevac. 1, Belgrade - Toronto : MESTE, January 15, 2021, MEST Journal, Vol. 9, pp. 8-14. 